\title{
Studying the Administrative Corruption Based on 3-Ramifications Analytical Model in the Pathology Theory and Suggesting Several Strategies for Controlling It (A Case Study: Administrations of Tehran Province)
}

\author{
Mahtab Jafari \\ Correspondence: Mahtab Jafari, Political Geography, Department of Political Geography, Faculty of Geography, \\ University of Tehran, Iran.
}

Received: January 4, 2018

Accepted: May 12, 2018 Online Published: May 18, 2018

doi:10.11114/ijlpa.v1i1.3285

URL: http://dx.doi.org/10.11114/ijlpa.v1i1.3285

\begin{abstract}
Administrative corruption is largely influenced by economic, political, social, cultural, and judicial systems and also, it has negative impacts on the legitimacy of political systems and the performance of administrative systems. Therefore, the aim of the current study is to identify the causes of the emergence and the prevalence of administrative corruption and to provide appropriate strategies for controlling and restricting the scope of administrative corruption. Hence, this research is of descriptive-analytical type and it is based on data collected by field methods. It should be noted that consistency and validity of the questionnaire has been examined with Cronbach's alpha and factor analysis, respectively. Then, non-parametric tests including binomial test and Friedman test have been used for testing the hypothesis. Ultimately, the results of this study showed that there are several factors such as lack of professional conscience, lack of adherence to ethics in the society, the sense of economic inequality in government employees in comparison with those in the other sectors, complexity of laws, etc., have significant influence on the emergence of administrative corruption. Also, some other factors such as existence of an efficient financial control system, effective administrative control, establishing some independent agencies for resolving the administrative corruption, intensification of the penalties, depoliticizing the administrative system, and applying efficient regulations can be effective in controlling and preventing the administrative corruption.
\end{abstract}

Keywords: Administrative Corruption, Controlling the Administrative Corruption, Pathology Theory, 3-Ramifications Analytical Model, Administrations of Tehran Province.

\section{Introduction}

In all of the societies, administrative system is seen as a functional and administrative aspect of the government, and is the way of communication between the government and people. All around the world, administrative systems are so important that people's judgment of evaluation of their political system are based on their administrative system and, if we consider types of organizations and the administrative institutions of a government and their functions as a way of differentiating the governments from each other, it will not be exaggeration. The philosophy behind the existence of the administrative system in every society is to enable a government to perform its duties for people in different political, economic, social and other areas and for the general purposes of the government. It is clear that performing these duties will ultimately lead to the legitimacy and survival of the political systems, in addition to ensuring social organization, order, and stability. Certainly, it is possible to achieve these goals only when the society has a clean and efficient administrative system. Obviously, if the administrative system loses its efficiency or gets corrupted for any reason, it can be expected that the system becomes one of the fundamental holes in the government, resulting in a disruption in the relationships between government and society. This will lead to disastrous consequences for political and social stability.

Administrative corruption is largely influenced by economic, social, judicial and cultural systems in any society and, at the same time, has negative effects on the legitimacy of the political system and the efficiency of administrative system and also three facts about administrative corruption includes inclusiveness, harmfulness, and controllability. Hence, the matter of administrative corruption and inefficiency of administrative systems has been a major concern for 
governments and political and social experts in all countries in the world. The remnants of the first governments formed in China and India represent the long history of governments' concern about the misuse of government jobs and, nowadays, along with the development of government activities in the administration of societies, this concern has become more important so that international agencies and institutions have also paid attention to it. Also, these agencies put practices on their agenda to deal with the administrative corruption in countries. It should be noted that the importance of this issue in Iran is even more than this, as Iran is the only country that its political system and the legitimacy of the political system are based on values and people's religious beliefs. Therefore, the purpose of this study is to address this problem and to control it.

According to what was stated, the research questions in this study for identifying the causes and prevalence of administrative corruption and providing appropriate strategies for controlling and restricting the scope of administrative corruption are: "Whether there is a significant relationship between administrative corruption and factors including the economic situation of employees, cultural characteristics of the society, organizational characteristics, quality and quantity of the laws, and individual characteristics of employees?", "Whether there is a significant relationship between controlling and monitoring methods and the reduction of administrative corruption?", "What are the most effective control methods?" The hypotheses that correspond to the questions mentioned above are as follows (respectively): "There is a significant relationship between the economic situation of employees, cultural characteristics of the society, organizational characteristics, quality and quantity of the laws, individual characteristics of employees and administrative corruption", and also "There is a significant relationship between controlling methods and the reduction of administrative corruption".

\section{Research Methodology}

The present study is an applied research carried out by descriptive-analytical method. Therefore, to analyze and evaluate the hypotheses, we have used findings obtain from a questionnaire (field research method), in addition to documents and electronic resources (library research method). Since the main topic of the current study is "the administrative system", and because the topic covers a wide area, we tried to take the employees of 51 offices of 96 administrations in Tehran Province as our statistical population and then, to collect the intended information. Since it wasn't possible to get in touch with all of the employees of the administrations (the entire statistical population, we have used the Cochran formula to calculate a sample size for an infinite population:

$$
\mathrm{N}=\frac{z^{2} \times p q}{d^{2}}
$$

Where:

$\mathrm{d}=$ The Acceptable margin of error (usually, equal to 0.05 );

$\mathrm{Z}=1.96$ (for $95 \%$ confidence);

$\mathrm{p}=$ the proportion of the population which has the attribute in question (this value can be obtained by making an approximate estimation of previous studies and by performing a preliminary study, or it can be considered equal to 0.5 , which gives the highest possible size); and

$\mathrm{q}=(1-\mathrm{p})$.

Therefore, the sample size is equal to 384 (95\% confidence). We have prepared 384 copies of the questionnaire; then, we delivered the copies to a number of employees of each administration, who have been sampled by simple random sampling method. Regarding that the present study is some kind of organizational Diagnosis in the administrative system of the country, it should be noted that the questionnaire was prepared in two parts. First section contains 14 questions and investigates the causes of administrative corruption based on three-ramification model in the organizational Diagnosis theory. The second section, which consists of six questions, investigates the most effective methods for controlling the administrative corruption. In order to test the hypotheses, we have used two non-parametric tests, namely the Friedman test, and the Binomial test. The questionnaire has been designed based on a Likert scale and the options of each item are ranged from 1 to 5 (1 means very lowly and 5 means highly). In order to perform the binomial test, first we specify a criterion or a mean based on this range, and next we'll calculate the number of people whose scores are higher/lower than the criterion; then, the hypotheses could be verified or rejected. In the equation used for the binomial test, P represents the probability of the presence of a state (success or verification of a hypothesis), and q represents the probability of the absence of the same state (failure or rejection of the hypothesis). Friedman test was used to categorize the hypotheses, and to rank the factors involved in the occurrence of administrative corruption, and the methods for control this phenomenon. 
It should to be noted that a factor analysis method was used prior to delivering the copies of the questionnaire to the respondents, in order to verify the validity of its items. The results of this analysis indicated that the items have sufficient validity for measuring the research variables. Then, we have evaluate the reliability of the items by the Cronbach's alpha method. The coefficient obtained by this method is equal to 0.711 . Since the minimum acceptable value is 0.7 , the obtained coefficient indicates that the items of the questionnaire are adequately reliable.

\section{Research findings}

\section{Causes of Administrative Corruption}

The studies carried out on administrative corruption showed that the causes of the formation of this phenomenon are highly complicated and diverse. Generally, the main causes of this phenomenon can be divided into three categories:

\section{A) Environmental causes (Context in the Three-ramification model)}

Among this group of causes affecting the occurrence and emergence of administrative corruption are the economic and cultural factors which includes kinship-based favoritism in society, lack of adherence to the ethical standards, economical issues in the society such as a misbalance between growth rate of inflation and that of employees' income, employees of government administrations who feel a sense of economic inequality when compare themselves to the employees of other sectors, and lack of collateral benefits for employees.

Generally, in the current administrative system, friendship-based appointments and employments for the organizational positions or taking/accepting bribe in an exchange of the positions have become a routine. Collusion between rich people, politicians, and the actors of administrative bureaucracy for passing the administrative system filters has become an accepted mainstream which resulted in corruption of the society, especially at the macro level (Rafi Pour, 2000:48).

\section{B) Behavioral cause (Content in the Three-ramification model)}

These causes includes the lack of professional conscience, individualistic traits, the level of risk-taking among the employees, and awareness of the rules and regulations among the clients.

Generally, in all countries (especially, the developed countries), there are eligibility requirements for appointing individuals to the administrative and organizational positions, and those who are appointed to this position must meet the requirements. A part of the eligibility requirements for occupying the administrative and government positions is allocated to the managers' personality traits, because the traits play an important role in the organizational behaviors. If an ineligible individual is selected for a post, corruption will be inevitable (Rafi Pour, 2000:48).

\section{C) Structural cause (Structure in the Three-ramification model)}

One of the facts in the current administrative system is that the administrative units are usually faced to a large number of rules and regulations; ambiguities of the administrative procedures and current work standards allow the agents to make any arbitrary decision and to take arbitrary actions. Additionally, complexity of administrative tasks and procedures also encourages the clients to offer bribe in order to accelerate the slow procedure. On the other hand, the low income of the employees of public services will reduce their resistance for accepting bribes, and they will get used to accepting such offers in the future. Among the structural causes of the administrative corruption are:

1-Structural and organizational issues. For example, the credits and the facilities provided for employees may not correspond to the objectives and activities of the organization. This can be due to constraints in human and financial resources or the weakness of internal controlling mechanisms.

2-Problems in the preparation and the implementation of the rules and regulations

3- Rules and regulations that not correspond to the needs and requirements of the society; changes in the rules; contradictive rules in some cases; ambiguities and abstract nature of some of the rules and regulations which may result in different interpretations; and the lack of conformity between the formulated guidelines and regulations and the articles of the relevant rules.

4-Issues and problems associated with recruiting, training, and retaining the experts and efficient individuals.

5-The performance of the previous managers and its influence on the performance of the current executive system (Rafi Pour, 2000:48).

Organizational Diagnosis Models

Organizational Diagnosis is based on the perception of how an organization works. Intellectual frameworks that apply the influential factors of organizational evolution to assess an organization are called "Diagnosis Models". The Diagnosis models play a crucial role in the organizational evolution plan (Zakeri et al., 2011:11). If we recognize the 
Diagnosis models, we would be able to formalize and institutionalize one of them according to the organizational requirements, so that by observing any problem in an organization, we can examine the interactions between different organizational elements from a systematic point of view, and we can minimize the harmful consequences of the pathologic phenomena by taking preventive and systematic actions. In this term, researchers and experts have presented models for organizational Diagnosis. In these models, organizational Diagnosis has been -evaluated from different perspectives. The most important organizational models are as follows: Marvin Weisbord's 7-Dimmensional Model, Harrison's Model, and Three-ramification Analytical Model (Ibid); in the current study, we have described Three-ramification Analytical Model:

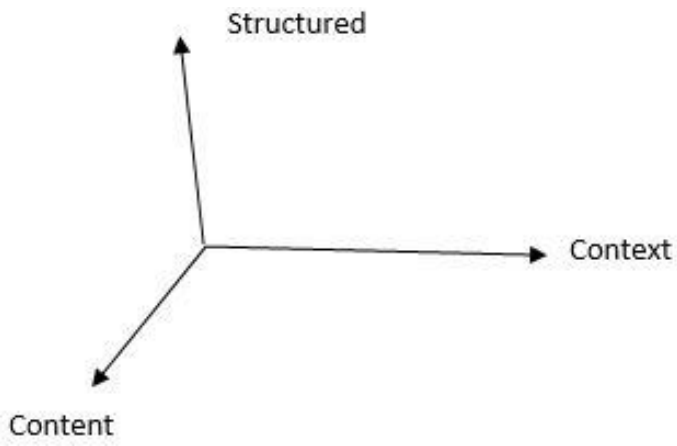

Reference: (Bahramzadeh et al., 2015: 66)

Figure 1. Three-ramification Analytical Model

Based on this model, the phenomenon of organization and management can be analyzed with regard to the components of the three categories of the model, i.e. the content, the structure, and the context. Content means all factors related to the human resources of the organization; e.g., motivation, spirit at work, and job satisfaction. Structural factors include a set of regular relations between the internal elements of an organization, which form the main body of the organization; e.g., organizational structure, and rules and regulations. Finally, contextual factors include the environment and the external circumstances that constitutes the foundation of content and structural factors (Tavakkoli Darestani and Shahbaz Moradi, 2008:100). This implies that all of the structural and content elements are based on the environment. No resource can be imagined without the environment (Abbas Zadeh, 2010:93). Therefore, all organizational events and phenomena can be analyzed, studied, and evaluated by Three-ramification theory. The model consists of three branches: structure, context, and content.

\section{Analysis}

In the current study, a 20-item questionnaire has been formulated with two separate sections, in order to answer to the following question: "Is there a significant relationship between administrative corruption and factors such as employees' economic status, cultural feature of the society, organizational features, quality and quantity of rules, and employees' characteristics?"; "Is there a significant relationship between the controlling methods and the reduction of administrative corruption?", "What are the most effective controlling methods?". Based on Three-ramification Model, the first section of this questionnaire consists of three categories: structure, content, and context. According to the following table, questions from 1 to 6 have been formulated in order to investigate the relationship between "the organizational rules and features" and "administrative corruption"; questions from 11 to 14 examine the relationship between "the cultural and economic features" and "administrative corruption". Also, the second section of the questionnaire, which includes questions from 15 to 20, investigates the relationship between "the controlling methods" and "administrative corruption". 
Table 1. Subject-based classification of the research questions

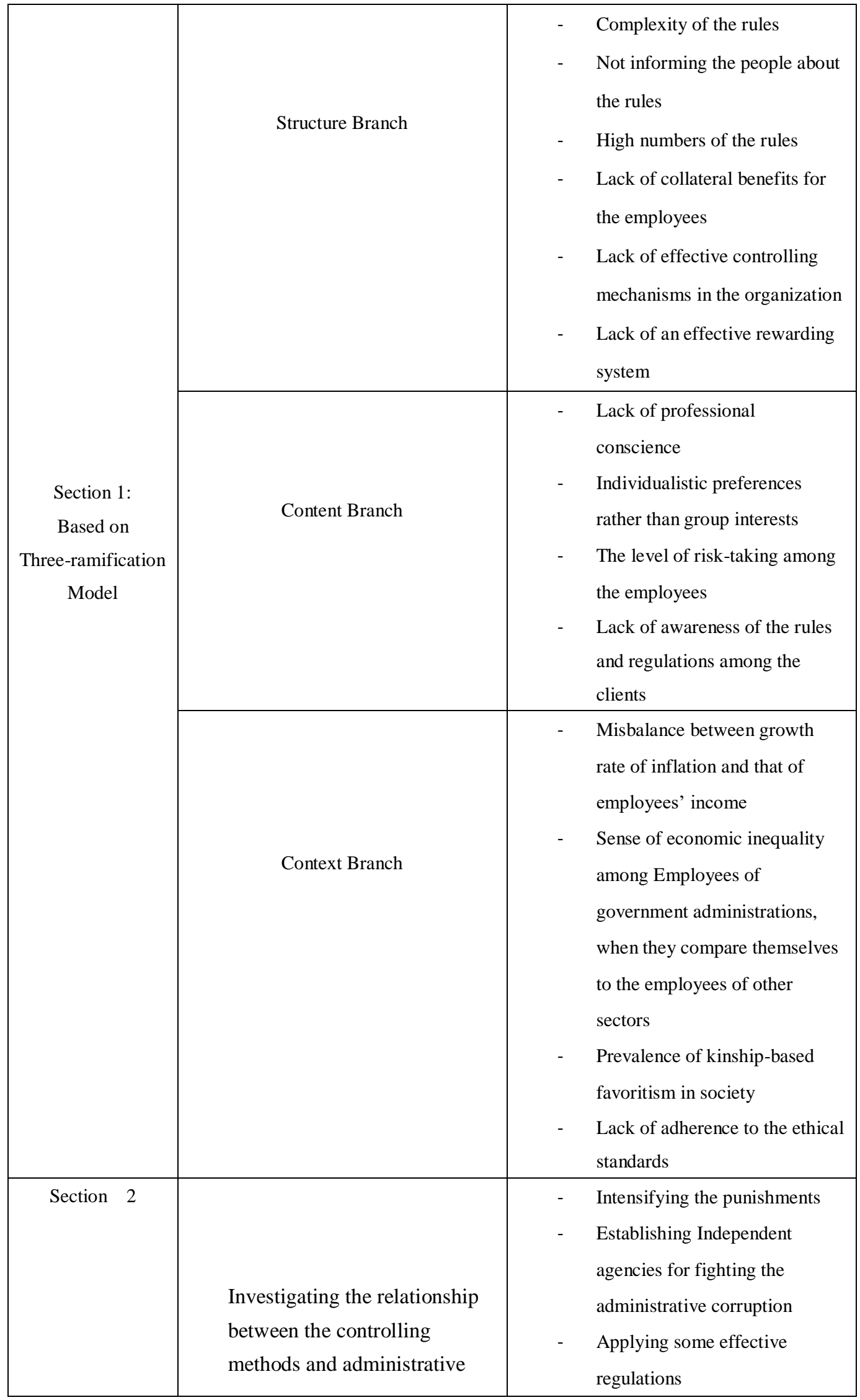




\begin{tabular}{|l|l|l|}
\hline corruption & - & Depoliticizing the \\
& & administrative system \\
& - & Practicing an effective \\
& & administrative control method \\
& - & Establishing an effective \\
& financial control system \\
\hline
\end{tabular}

\section{A) Binomial test}

Using a binomial test, we examined the relationship the intended variable (administrative corruption) and all other research variables. The scoring scale of questions related to each variable is based on Likert scale, and ranged from 1 to 5. This 5-point scale has three parts: positive, negative, and neutral. Therefore, the probability of disagreement or neutrality about the relationship between the two variables in each question is 0.6. We have conducted binomial test for each question, and the results have been presented in the following table. As an example, we have presented "the impact of lack of adherence to moral standards" on "administrative corruption".

Null Hypothesis (H0): Lack of adherence to the moral standards among the society members has no influence on the administrative corruption $(\mathrm{H} 0=\mathrm{p} \leqslant 0.6)$.

Alternative Hypothesis (H1): Lack of adherence to the moral standards among the society members influences the administrative corruption ( $\mathrm{H} 1=\mathrm{p}>0.6)$.

Table 2. Results of the binomial test conducted on the relevant questions

\begin{tabular}{|c|c|c|c|c|c|}
\hline Research variables & $\begin{array}{c}\text { Number of } \\
\text { questions }\end{array}$ & Observed ratio & Test ratio & Significance level & $\begin{array}{c}\text { Verification/Rejection of the } \\
\text { variable }\end{array}$ \\
\hline $\begin{array}{c}\text { Complexity of the rules. } \\
\text { Group No. } 1<=0.6 \\
\text { Group No. } 2>0.6\end{array}$ & $\begin{array}{c}0 \\
384\end{array}$ & $\begin{array}{c}.0 \\
1.0\end{array}$ & 0.6 & .000 & $\begin{array}{c}\text { Impact of the variable is } \\
\text { verified }\end{array}$ \\
\hline $\begin{array}{l}\text { Not informing the people about the } \\
\text { rules } \\
\text { Group No. } 1<=0.6 \\
\text { Group No. } 2>0.6\end{array}$ & $\begin{array}{c}0 \\
384\end{array}$ & $\begin{array}{c}.0 \\
1.0\end{array}$ & 0.6 & .000 & $\begin{array}{c}\text { Impact of the variable is } \\
\text { verified }\end{array}$ \\
\hline $\begin{array}{c}\text { High numbers of the rules } \\
\text { Group No. } 1<=0.6 \\
\text { Group No. } 2>0.6\end{array}$ & $\begin{array}{c}0 \\
384 \\
\end{array}$ & $\begin{array}{c}.0 \\
1.0 \\
\end{array}$ & 0.6 & .000 & $\begin{array}{c}\text { Impact of the variable is } \\
\text { verified }\end{array}$ \\
\hline $\begin{array}{c}\text { Lack of collateral benefits for the } \\
\text { employees } \\
\text { Group No. } 1<=0.6 \\
\text { Group No. } 2>0.6\end{array}$ & $\begin{array}{c}0 \\
384 \\
\end{array}$ & $\begin{array}{c}.0 \\
1.0 \\
\end{array}$ & 0.6 & .000 & $\begin{array}{c}\text { Impact of the variable is } \\
\text { verified }\end{array}$ \\
\hline $\begin{array}{c}\text { Lack of effective controlling } \\
\text { mechanisms in the organization } \\
\text { Group No. } 1<=0.6 \\
\text { Group No. } 2>0.6\end{array}$ & $\begin{array}{c}0 \\
384\end{array}$ & $\begin{array}{c}.0 \\
1.0\end{array}$ & 0.6 & .000 & $\begin{array}{c}\text { Impact of the variable is } \\
\text { verified }\end{array}$ \\
\hline $\begin{array}{c}\text { Lack of an effective rewarding system } \\
\qquad \begin{array}{c}\text { Group No. } 1<=0.6 \\
\text { Group No. } 2>0.6\end{array}\end{array}$ & $\begin{array}{c}0 \\
384 \\
\end{array}$ & $\begin{array}{c}.0 \\
1.0\end{array}$ & 0.6 & .000 & $\begin{array}{c}\text { Impact of the variable is } \\
\text { verified }\end{array}$ \\
\hline $\begin{array}{c}\text { Lack of professional conscience } \\
\text { Group No. } 1<=0.6 \\
\text { Group No. } 2>0.6\end{array}$ & $\begin{array}{c}0 \\
384 \\
\end{array}$ & $\begin{array}{c}.0 \\
1.0 \\
\end{array}$ & 0.6 & .000 & $\begin{array}{c}\text { Impact of the variable is } \\
\text { verified }\end{array}$ \\
\hline $\begin{array}{c}\text { Individualistic preferences rather } \\
\text { than group interests } \\
\text { Group No. } 1<=0.6 \\
\text { Group No. } 2>0.6\end{array}$ & $\begin{array}{c}0 \\
384 \\
\end{array}$ & $\begin{array}{c}.0 \\
1.0 \\
\end{array}$ & 0.6 & .000 & $\begin{array}{c}\text { Impact of the variable is } \\
\text { verified }\end{array}$ \\
\hline The level of risk-taking among the & & & & & Impact of the variable is \\
\hline
\end{tabular}




\begin{tabular}{|c|c|c|c|c|c|}
\hline $\begin{array}{c}\text { employees } \\
\text { Group No. } 1<=0.6 \\
\text { Group No. } 2>0.6\end{array}$ & $\begin{array}{c}0 \\
384 \\
\end{array}$ & $\begin{array}{c}.0 \\
1.0 \\
\end{array}$ & 0.6 & .000 & verified \\
\hline $\begin{array}{c}\text { Lack of awareness of the rules and } \\
\text { regulations among the clients } \\
\text { Group No. } 1<=0.6 \\
\text { Group No. } 2>0.6\end{array}$ & $\begin{array}{c}0 \\
384 \\
\end{array}$ & $\begin{array}{c}.0 \\
1.0 \\
\end{array}$ & 0.6 & .000 & $\begin{array}{c}\text { Impact of the variable is } \\
\text { verified }\end{array}$ \\
\hline $\begin{array}{c}\text { Misbalance between growth rate of } \\
\text { inflation and that of employees' } \\
\text { income } \\
\text { Group No. } 1<=0.6 \\
\text { Group No. } 2>0.6\end{array}$ & $\begin{array}{c}0 \\
384 \\
\end{array}$ & $\begin{array}{c}.0 \\
1.0 \\
\end{array}$ & 0.6 & .000 & $\begin{array}{c}\text { Impact of the variable is } \\
\text { verified }\end{array}$ \\
\hline $\begin{array}{l}\text { Sense of economic inequality in the } \\
\text { employees of government } \\
\text { administrations, when they compare } \\
\text { themselves to the employees of other } \\
\text { sectors } \\
\text { Group No. } 1<=0.6 \\
\text { Group No. } 2>0.6\end{array}$ & $\begin{array}{c}0 \\
384 \\
\end{array}$ & $\begin{array}{c}.0 \\
1.0 \\
\end{array}$ & 0.6 & .000 & $\begin{array}{c}\text { Impact of the variable is } \\
\text { verified }\end{array}$ \\
\hline $\begin{array}{c}\text { Prevalence of kinship-based favoritism } \\
\text { in society } \\
\text { Group No. } 1<=0.6 \\
\text { Group No. } 2>0.6\end{array}$ & $\begin{array}{c}0 \\
384 \\
\end{array}$ & $\begin{array}{r}.0 \\
1.0 \\
\end{array}$ & 0.6 & .000 & $\begin{array}{c}\text { Impact of the variable is } \\
\text { verified }\end{array}$ \\
\hline $\begin{array}{l}\text { Lack of adherence to the ethical } \\
\text { standards } \\
\text { Group No. } 1<=0.6 \\
\text { Group No. } 2>0.6\end{array}$ & $\begin{array}{c}0 \\
384 \\
\end{array}$ & $\begin{array}{l}.0 \\
1.0 \\
\end{array}$ & 0.6 & .000 & $\begin{array}{c}\text { Impact of the variable is } \\
\text { verified }\end{array}$ \\
\hline $\begin{array}{c}\text { Intensifying the punishments } \\
\text { Group No. } 1<=0.6 \\
\text { Group No. } 2>0.6\end{array}$ & $\begin{array}{c}0 \\
384 \\
\end{array}$ & $\begin{array}{c}.0 \\
1.0 \\
\end{array}$ & 0.6 & .000 & $\begin{array}{c}\text { Impact of the variable is } \\
\text { verified }\end{array}$ \\
\hline $\begin{array}{l}\text { Establishing Independent agencies for } \\
\text { fighting the administrative corruption } \\
\text { Group No. } 1<=0.6 \\
\text { Group No. } 2>0.6\end{array}$ & $\begin{array}{c}0 \\
384 \\
\end{array}$ & $\begin{array}{c}.0 \\
1.0\end{array}$ & 0.6 & .000 & $\begin{array}{c}\text { Impact of the variable is } \\
\text { verified }\end{array}$ \\
\hline $\begin{array}{l}\text { Applying some effective regulations } \\
\text { Group No. } 1<=0.6 \\
\text { Group No. } 2>0.6\end{array}$ & $\begin{array}{c}0 \\
384 \\
\end{array}$ & $\begin{array}{l}.0 \\
1.0 \\
\end{array}$ & 0.6 & .000 & $\begin{array}{c}\text { Impact of the variable is } \\
\text { verified }\end{array}$ \\
\hline $\begin{array}{c}\text { Depoliticizing the administrative } \\
\text { system } \\
\text { Group No. } 1<=0.6 \\
\text { Group No. } 2>0.6\end{array}$ & $\begin{array}{c}0 \\
384 \\
\end{array}$ & $\begin{array}{c}.0 \\
1.0 \\
\end{array}$ & 0.6 & .000 & $\begin{array}{c}\text { Impact of the variable is } \\
\text { verified }\end{array}$ \\
\hline $\begin{array}{c}\text { Practicing an effective administrative } \\
\text { control method } \\
\text { Group No. } 1<=0.6 \\
\text { Group No. } 2>0.6\end{array}$ & $\begin{array}{c}0 \\
384 \\
\end{array}$ & $\begin{array}{c}.0 \\
1.0 \\
\end{array}$ & 0.6 & .000 & $\begin{array}{c}\text { Impact of the variable is } \\
\text { verified }\end{array}$ \\
\hline $\begin{array}{c}\text { Establishing an effective financial } \\
\text { control system } \\
\text { Group No. } 1<=0.6 \\
\text { Group No. } 2>0.6\end{array}$ & $\begin{array}{c}0 \\
384 \\
\end{array}$ & $\begin{array}{l}.0 \\
1.0 \\
\end{array}$ & 0.6 & .000 & $\begin{array}{c}\text { Impact of the variable is } \\
\text { verified }\end{array}$ \\
\hline
\end{tabular}


According to the above table, the results of the relevant questions show that there is a significant relationship between "the elements of structure, content, and context branches, and the controlling methods" and "administrative corruption". In other words, the above table indicates the relationship between "complexity of the rules, not informing the people about the rules, high numbers of the rules, lack of collateral benefits for the employees, lack of effective controlling mechanisms in the organization, lack of an effective rewarding system, lack of professional conscience, individualistic preferences rather than group interests, the level of risk-taking among the employees, lack of awareness of the rules and regulations among the clients, misbalance between growth rate of inflation and that of employees' income, sense of economic inequality in the employees of government administrations, when they compare themselves to the employees of other sectors, prevalence of kinship-based favoritism in society, lack of adherence to the ethical standards, intensifying the punishments, establishing Independent agencies for fighting the administrative corruption, applying some effective regulations, depoliticizing the administrative system, practicing an effective administrative control method, and establishing an effective financial control system" and "administrative corruption" (the dependent variable). The significance levels in this test were .000 or smaller than 0.5 . Therefore, the statistics obtained by conducting the test on the above components is placed within the $\mathrm{H} 1$ range and there is a significant relationship between these components and administrative corruption. Also, the H0 hypothesis was rejected for all of the components.

\section{B) Friedman test}

Friedman test has been used to specify the importance of the elements of structure, content, and context branches in three-ramification model, and to identify their influences on administrative corruption. The results of this test have been presented in Table 3. The importance of each controlling method and the influence it has on administrative corruption have been tested separately, and the results have been presented in Table 4.

Table 3. Components that influence the emergence of administrative corruption, listed in descending order of importance

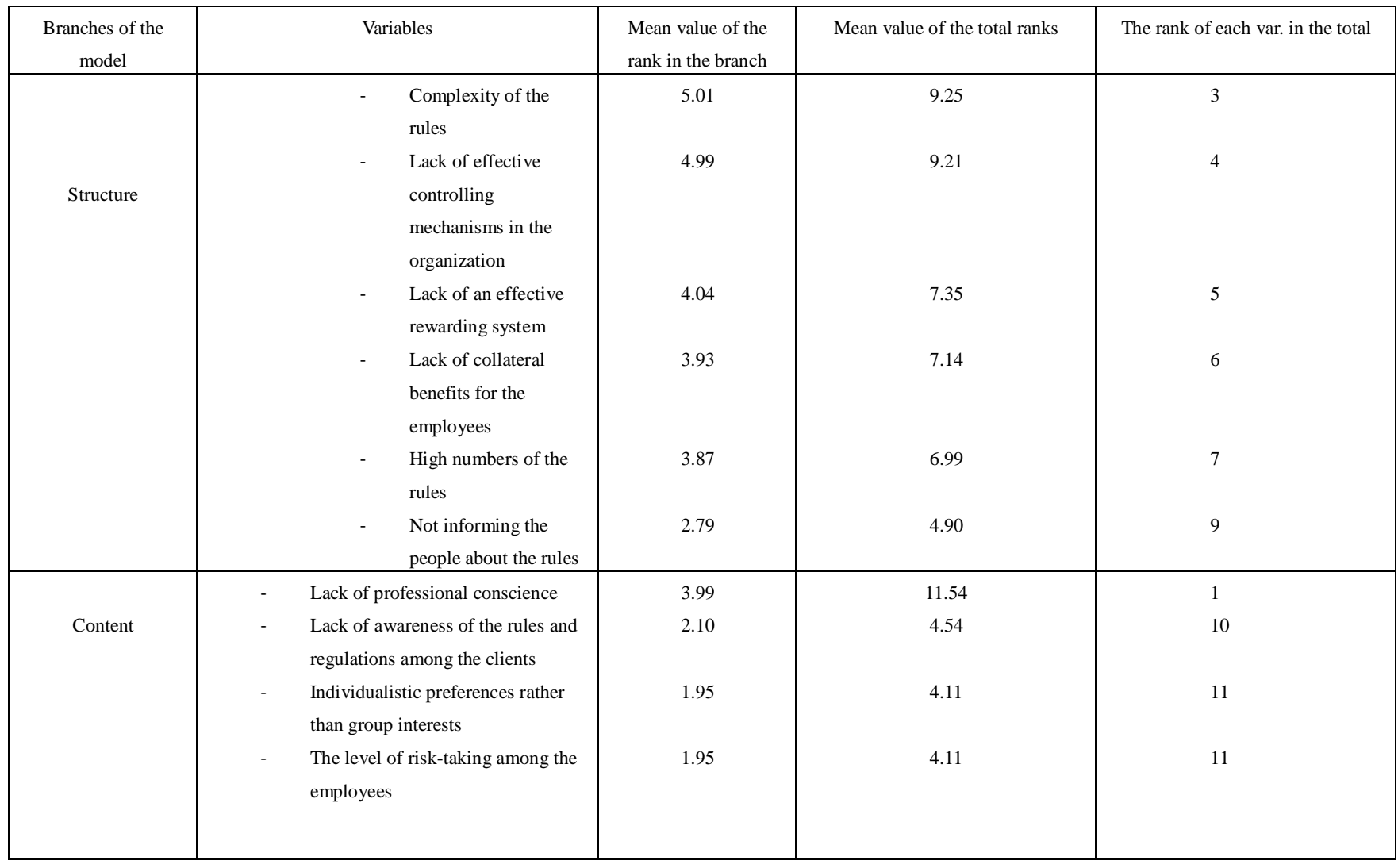




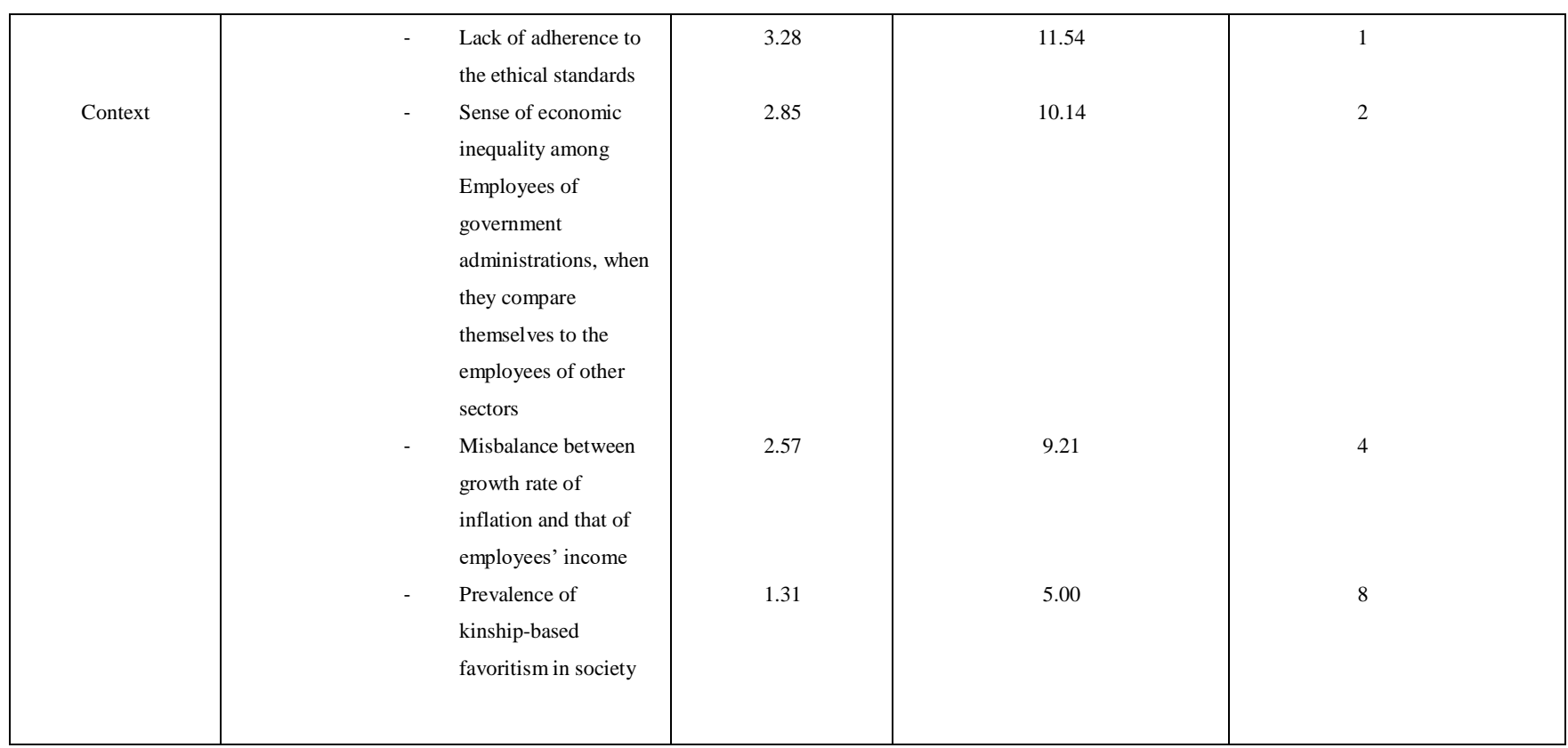

As you see, the lack of professional conscience, the sense of economic inequality among employees, and the complexity of the rules are the first, second and third factor affecting the emergence of administrative corruption, respectively. Also, other components such as the lack of effective controlling mechanisms in the organization, the lack of an effective rewarding system, the lack of collateral benefits for the employees, high numbers of the rules, and not informing the people about the rules are placed in the other positions based on their importance.

Table 4. Ranking the components related to the controlling methods of administrative corruption

\begin{tabular}{|c|c|c|c|}
\hline 2nd Section & Variables & $\begin{array}{c}\text { Mean } \\
\text { rank }\end{array}$ & Rank \\
\hline $\begin{array}{l}\text { Investigating the relationship } \\
\text { between "the controlling } \\
\text { methods" and "administrative } \\
\text { corruption }\end{array}$ & $\begin{array}{l}\text { - Establishing an effective } \\
\text { financial control system } \\
\text { - } \quad \text { Practicing an effective } \\
\text { administrative control } \\
\text { method } \\
\text { - } \quad \text { Establishing Independent } \\
\text { agencies for fighting the } \\
\text { administrative corruption } \\
\text { - Intensifying the } \\
\text { punishments } \\
\text { Depoliticizing the } \\
\text { administrative system } \\
\text { Applying some effective } \\
\text { regulations }\end{array}$ & $\begin{array}{l}2.74 \\
2.61 \\
2.56\end{array}$ & 3 \\
\hline
\end{tabular}


As you can see, the first three effective methods for controlling the administrative corruptions are establishing an effective financial control system, practicing an effective administrative control method, and establishing Independent agencies for fighting the administrative corruption, respectively. Methods including the intensification of the punishments, depoliticizing the administrative system, and applying some effective regulations are placed at the next positions.

\section{Conclusion}

According to the results of the present study, we believe that administrative corruption affects the legitimacy of the political system, the efficiency of the administrative system, and the development of the country, as much as it is affected by the economic, social, political, judicial, and cultural systems. Also, the studies carried out on administrative corruption have indicated that this phenomenon is getting more complex daily. This indicates the necessity and the importance of using comprehensive solutions to eliminate the phenomenon. It should be mentioned that, in order to handle the corruption efficiently in each country, it's necessary for the people and the government officials of that country to understand the phenomenon properly.

Hence, in the current study, we have presented a set of the most important causes of the emergence of administrative corruption in the administrations of Tehran Province, based on Three-ramification model in the Organizational Diagnosis theory. Also, we have presented the most effective methods for controlling the administrative corruption. Regarding the results of this study, and based on Three-ramification model, the most important causes of administrative corruption belong to the content and context branches, and the other causes belong to the structure branch. These causes are as follows:

1. Lack of professional conscience and the lack of adherence to the ethical standards (context and content)

2. Sense of economic inequality among Employees of government administrations, when they compare themselves to the employees of other sectors (context)

3. Complexity of the rules (structure)

4. Lack of effective controlling mechanisms in the organization (structure)

5. Lack of an effective rewarding system (structure)

Also, according to table 4, the most effective methods for controlling the administrative corruption have been listed in descending order of effectiveness:

1. Establishing an effective financial control system

2. Practicing an effective administrative control method

3. Establishing Independent agencies for fighting the administrative corruption

4. Intensifying the punishments

5. Depoliticizing the administrative system

6. Applying some effective regulations

Based on this, we have provided solutions to eliminate the corruption in the administrative system, as well as to reform the system:

1. Making the financial systems more systematic by enhancing them.

2. Monitoring the wealth of government employees and their families.

3. Strengthening institutions and regulatory bodies, such as the audit agencies and using the informational systems.

4. Solving the problem of multiple prices for a single item, eliminating the prerequisites of rent-seeking, and breaking the monopoly.

5. Giving the public access to the government information, as well as encouraging employees and citizens to reveal administrative corruption, and rewarding the individual who reveals corruption.

6. Creating appropriate conditions for the involvement of the public opinion, non-governmental organizations, and the media for monitoring the performance of the administrative system.

7. Providing freedom and immunity for the press, so that they will be able to reveal administrative corruption.

8. Reforming the methods of rewarding and punishment in the administrative system.

9. Reforming the administrative system by improving its structure and rules, and eliminating redundant regulations. 
10. Reforming the rules implemented for the recruitment and selection of employees and managers in the administrative system.

11. Developing the E-Government

12. Performing cultural and educational practices to criticize and condemn administrative violations.

\section{References}

Abbas Zadeh, Hassan (2010) Pathology of Human Resources Management in the National Oil Industry, Quarterly Journal of Human Resource Management in The Oil Industry, Vol 4. Issue. 12, pp. 89-112.

Bahramzadeh, Hossein Ali, Amiri, Hooshang, Ghadiri, Ramin. (2015), Pathology of Human Resources Management in Mazandaran University of Medical Sciences On the basis three ramifications model, Quarterly Journal of Educational Psychology, Vol 6. Issue. 2, pp. 59- 82.

McFillen, J. M, Deborah, A, ONeil, William, K, Blazer \& Glenn H, Varney. (2013), Organizational Diagnosis: An Evidence- based Approach, Journal of Change Management, Vol.13, No. 2, pp 223- 246.

Rafi Pour, Faramarz (2000), Development and Contradiction, Tehran: Publication Co.

Rafi Pour, Faramarz (2009), Social Cancer Corruption, Tehran: Publication Co., Second Edition.

Rahimi, H, Siadat, A, Hoveida, R, Shahin, A, Nasrabadi, H.N, Arbabisarjou, A. (2011) The Analysis of Organizational Diagnosis on Based six Box Model in University, Higher Education Studies, Vol.1, pp 84- 92.

Tavakoli Darestani, Shaghayegh and Saeed Shahbaz Moradi. (2008) Pathology of human resources management with the aim of improvement and development, Quarterly Journal of Human Resource Management in The Oil Industry, Vol 2. Issue. 4.

Zakeri Pour, Gholamreza, Reza Gholi, Fahimeh, Ahmad Abadi, Ahmad. (2011), Human Resources Pathology of fateb in order to Improving Development, Quarterly Journal of Management Development and Human Resources and Logistics, Vol 6. Issue. 22.

\section{Copyrights}

Copyright for this article is retained by the author(s), with first publication rights granted to the journal.

This is an open-access article distributed under the terms and conditions of the Creative Commons Attribution License which permits unrestricted use, distribution, and reproduction in any medium, provided the original work is properly cited. 